\title{
PERLINDUNGAN HUKUM PEMANGGILAN DAN PENGAMBILAN MINUTA AKTA NOTARIS PASKA BERLAKUNYA UU NO. 2 TAHUN 2014 TENTANG PERUBAHAN ATAS UU NO. 30 TAHUN 2004 TENTANG JABATAN NOTARIS (UUJN-P)
}

\author{
Oleh: Muh. Rikaz Prabowo \\ Magister Kenotariatan Universitas Gadjah Mada \\ E-mail: rikaz.prabowo@gmil.com
}

\begin{abstract}
This paper discusses legal protection for Notaries-Function; in terms of the request upon the copies of the deed minuta, Notarial-deeds protocol, and the calling of Notaries-vocation in legal processes. The identification of the problemis to understand mechanisms of legal protections for Notaries and MKN's roles and to discussnotaries' refusal rights and refusal obligation. Based on the literature review and studies on the literatures and legal resources, it can be concluded that: First, the mechanisms of legal protection for request upon the copies of the minuta, the protocol takin of the notary, and the calling of notary for investigation purposes, by investigating-officers, public-prosecutors and judges- require approval of the Regional Supervisory Council as stated in Article 66 paragraph (1) Act Number 30 2004. In 2013 "the phrase of the MPD's approval" is canceled by Constitutional Court through the decree number 49/PUU/X/2012 for not having legal binding. Second, the MKN is a new agency formed with the establishment of the Act Number 22014 concerning the amendment of the Act Number 302004 concerning Notaries' functions (UUJN-P). One of MKN authorities was similar with authorities of the MPD before it was revoked by the MK in 2013. However, the MK had not been established because the Permenkumham on MKS was still being harmonized. Third, the Refusal-Rights are rights for not speaking and giving any statements related to deeds, as a witness in prosecutions and courts. These rights are based on Articles in the Acts, such as the KUHAP, KUH Perdata, HIR and the Act Number 51986 concerning state administrative law. The Act Number 30 Year 2004 concerning Notaries-functions (UUJN-P) stipulates this provisions as refusal-obligations which mean that it must be executed imperatively, based on the Article 4 paragraph (2), the Article 16 paragraph (1) letter f, and the Article 54 clause (1). The violation of these obligations shall be the subject to administrative sanctions ranging from warning up to dishonorable discharge by the UUJN-P. Criminal sanctions rely on general provisions of through KUHAP, especially the Article 322 concerning violations for divulging confidential information giving away in functions.
\end{abstract}

Keywords: UUJN-P, Notaries, MKN, refusal-Rights, refusal -Obligations. 


\section{A. LATAR BELAKANG}

Jabatan Notaris yang dijabat oleh seseorang yang berstatus sebagai pejabat umum memiliki wewenang dalam membuat akta otentik dan berbagai kewenangan lainnya, khususnya akta-akta otentik tersebut dalam bidang hukum keperdataan. Oleh karena kewenangan Notaris yang berstatus pejabat umum, maka mulai dari per-syaratan, pendidikan, formasi jabatan, hingga etika dalam melaksanakan jabatan di-atur oleh sebuah undang-undang. Notaris juga terikat oleh sebuah sumpah jabatan yang akan melekat sampai tidak menjabat lagi.

Peranan Notaris sangat besar baik bagi masyarakat dan dalam rangka membantu tugas pemerintah. Maka sudah selayaknya Notaris mendapatkan perlindungan hukum yang memadai dalam menjalankan jabatannya, terutama apabila seorang No-taris dipanggil atau diminta minuta aktanya oleh Kepolisian, Kejaksaan, ataupun Pengadilan. UU No. 30 Tahun 2004 yang kemudian telah dirubah dengan UU No. 2 Ta-hun 2014 menyebutkan bahwa pemanggilan dan pengambilan fotokopi minuta akta hingga protokol Notaris diharuskan mendapatkan persetujuan dari Majelis Penga-was Daerah (lihat Pasal 66 UU No. 30 Tahun 2004).

Akan tetapi, pada tahun 2013 lewat keputusan Mahkamah Konstitusi RI nomor: 49/PUU-X/2012 memutuskan untuk meniadakan atau mengakhiri kewenangan Majelis Pengawas Daerah (MPD) yang tercantum dalam Pasal 66 ayat (1) UUJN. Maka dengan kata lain tidak diperlukan lagi persetujuan MPD dalam memanggil Nota-ris atau mengambil fotokopi minuta akta dan/atau protokol Notaris. Hal ini sungguh disayangkan dan perlu mendapat perhatian serius dari organisasi jabatan Notaris, seakan jabatannya mudah sekali untuk dikriminalisasi.

Pada 15 Januari 2014 UU No. 2 Tahun 2014 tentang Perubahan Atas UU No. 30 Tahun 2004 tentang Jabatan Notaris (UUJN-P) berhasil diundangkan. UU ini menjadi harapan kembali bagi Notaris dalam mendapatkan perlindungan hukum dalam menjalankan jabatannya. Berdasarkan UU tersebut, muncul badan baru yang bernama Majelis Kehormatan Notaris (MKN). MKN inilah nantinya yang dapat memberikan izin atau tidak terhadap pemanggilan Notaris dan pengambil minuta akta untuk pro-ses peradilan (lihat Pasal 66 UUJN-P). Namun hingga saat ini badan tersebut belum secara formal dibentuk hal ini menjadi problematika apabila ada Notaris yang terjerat kasus hukum.

Tulisan ini memuat beberapa rumusan masalah yang akan dibahas lebih lanjut pada bagian pembahasan. Pertama, mekanisme perlindungan hukum bagi Notaris dan peran Majelis Pengawas Daerah (MPD). Kedua, munculnya badan MKN dalam UU No. 2 Tahun 2014 tentang Perubahan Atas UU No. 30 Tahun 2004 tentang Jabatan No-taris. Ketiga, tentang Hak Ingkar dan Kewajiban Ingkar sebagai komponen perlindu-ngan hukum yang integral bagi jabatan Notaris. 
Diterbitkan oleh Fakultas Hukum

Universitas Ahmad Dahlan

\section{B. PEMBAHASAN}

\section{Mekanisme Perlindungan Hukum bagi Notaris dan Peran Majelis Pengawas Daerah}

Notaris sebagai pejabat umum yang diangkat dan diberhentikan oleh pemerintah serta mengemban amanah sebagian tugas pemerintah dalam bidang hukum keperdataan, selayaknya mendapatkan sebuah perlindungan hukum dalam menjalankan jabatannya. Ada prinsip hukum yang menyebutkan bahwa seseorang tidak bi-sa dipidana karena melakukan perbuatan untuk melaksanakan ketentuan undang-undang, hal ini tertuang dalam Pasal 50 KUHP. Menurut R. Soesilo (1995: 66) apa yang telah diharuskan atau diperintahkan oleh suatu UU, tidak mungkin diancam hukuman dengan UU yang lain. Menjalankan UU artinya tidak hanya terbatas pada melakukan perbuatan-perbuatan yang diperintahkan oleh UU, akan tetapi lebih luas lagi ialah meliputi pula perbuatan-perbuatan yang dilakukan atas wewenang yang diberikan oleh suatu UU.

Perlindungan hukum tersebut semata-mata bukan digunakan dalam artian bahwa Notaris adalah jabatan yang kebal hukum, akan tetapi perlindungan hukum tersebut untuk profesionalitas Notaris. Terutama untuk menjaga kepentingan penghadap yang telah dituangkan dalam akta otentik, di mana akta tersebut akan menjadi sebuah arsip negara yang patut dilindungi.

Mekanisme perlindungan bagi Notaris dalam ancaman pemanggilan dalam proses peradilan hingga pengambilan minuta akta dan protokol Notaris, diatur dalam Pasal 66 ayat (1) BAB VIII tentang Pengambilan Minuta akta dan Pemanggilan Notaris. Pasal tersebut berbunyi:

\section{Pasal 66}

(1) Untuk kepentingan proses peradilan, penyidik, penuntut umum, atau hakim dengan persetujuan Majelis Pengawas Daerah berwenang

a. Mengambil fotokopi Minuta akta/dan atau surat-surat yang dilekatkan pada minuta akta atau protokol Notaris dalam penyimpanan Notaris;

b. Memanggil Notaris untuk hadir dalam pemeriksaan yang berkaitan deng-an akta yang dibuatnya atau protokol Notaris yang berada dalam penyim-panan Notaris.

Seperti yang telah disebutkan di atas, penyidik, penuntut umum, dan hakim baru bisa memanggil seorang Notaris ataupun mengambil fotokopi minuta akta atau protokol Notaris hanya apabila telah memperoleh persetujuan Majelis Pengawas Dae-rah (MPD). Majelis Pengawas adalah suatu badan yang mempunyai kewenangan dan kewajiban untuk melaksanakan pembinaan dan pengawasan terhadap Notaris (Pasal 1 angka 6 UU No. 2 Tahun 2014). Majelis Pengawas memiliki kedudukan di tiap dae-rah kabupaten/kota yang disebut Majelis Pengawas Daerah (MPD), tiap provin-si/daerah istimewa/daerah khusus yang disebut Majelis 
Pengawas Wilayah (MPW), dan berkedudukan di ibukota negara atau Majelis Pengawas Pusat (MPW).

Pengawasan atas Notaris sebenarnya dilakukan oleh Menteri, yang kemudian Menteri membentuk Majelis Pengawas yang beranggotakan 9 orang dari perwakilan pemerintah, organisasi Notaris, dan ahli/akademisi. Menurut Pasal 67 ayat (5) UUJN, pengawasan terhadap Notaris mencakup perilaku Notaris dan pelaksanaan jabatan Notaris. Majelis Pengawas berwenang melakukan sidang untuk memeriksa hal-hal yang berkaitan dengan: (1) adanya dugaan pelanggaran kode etik; (2) adanya dugaan pelanggaran tugas jabatan Notaris, (3) perilaku para Notaris di luar menjalankan tu-gas jabatanya sebagai Notaris yang dapat mengganggu atau mempengaruhi pelak-sanaan tugas jabatan Notaris (Adjie, 2008: 171) (lihat Pasal 70 huruf a, Pasal 73 ayat (1) huruf a dan b, Pasal 77 huruf a dan b UUJN).

Persidangan oleh MPD itulah yang kemudian dijadikan dasar persetujuan dikabulkan atau ditolaknya permintaan untuk pemanggilan Notaris, termasuk persetu-juan untuk pengambilan fotokopi Minuta akta dan Protokol Notaris untuk kepen-tingan proses peradi-lan. Pasal 66 ayat (1) kemudian diajukan ke Mahkamah Konsti-tusi (MK) pada 2012 oleh seorang Advokat untuk diuji materil. Hasilnya lewat Kepu-tusan MK RI No. 49/PUU/X/2012 permohonan itu dikabulkan. Adanya frasa "dengan persetujuan Majelis Pengawas Daerah", menurut MK bertentangan dengan UUD NRI 1945 dan tidak mem-punyai kekuatan hukum mengikat.

Putusan MK yang menganulir perlunya persetujuan dari MPD, terkait izin pe-manggilan Notaris dan pengambilan fotokopi minuta akta maupun protokol Notaris membuat kewibawaan jabatan Notaris berada dalam posisi yang mengkhawatirkan. Hal ini membuat jabatan Notaris menjadi mudah dikriminalisasi dan bisa saja Polisi ataupun Penyidik sesuka hati menjemput atau memeriksa Notaris.

Menurut Syafran Sofyan (2015: 4-5), ada beberapa hal yang perlu dipertimba-ngan paska berlakunya putusan MK tersebut terkait pemanggilan Notaris dan pe-ngambilan fotokopi minuta akta maupun protokol Notaris dalam proses peradilan oleh Kepolisian, Kejaksaan, ataupun Hakim, yakni:

a. Meminta dengan sangat kepada penegak hukum bahwa Notaris selaku pe-jabat umum harus dijaga wibawa dan kehormatannya, sehingga diper-lakukan khusus dalam rangka menjaga harkat martabat Notaris dalam proses peradilan, dan di-perlukan sikap kehati-hatian penegakan hukum dalam melakukan tindakan tan-pa mencederai prinsip negara hukum.

b. Mengusahakan agar penegak hukum melakukan koordinasi dengan MPD manakala ada Notaris yang dipanggil untuk hadir dalam pemeriksaan yang berkaitan dengan akta. 
Diterbitkan oleh Fakultas Hukum

Universitas Ahmad Dahlan

\section{Munculnya Majelis Kehormatan Notaris dalam UU No. 2 Tahun 2014 Tentang Perubahan Atas UU No. 30 Tahun 2004 Tentang Jabatan Notaris (UUJN-P)}

Transformasi dasar hukum sebagai acuan untuk menjalankan jabatan Notaris dalam perjalanannya mengalami perubahan atau revisi. UU No. 30 Tahun 2004 ten-tang Jabatan Notaris diubah dengan UU No. 2 Tahun 2014 (UUJN-P) yang mulai ber-laku pada 15 Januari 2014.

Sejumlah pertimbangan perlunya diadakan perubahan pada UUJN adalah karena jabatan Notaris sebagai pejabat umum yang menjalankan profesi dalam memberikan jasa hukum kepada masyarakat perlu mendapatkan perlindungan dan jaminan demi tercapainya kepastian hukum. Beberapa ketentuan tentang UUJN juga dianggap sudah tidak sesuai lagi dengan perkembangan hukum dan kebutuhan masya-rakat sehingga diperlukannya peruba-han.

Jika tidak berlebihan, menurut penulis, dapat diduga bahwasanya perubahan pada UUJN ini memang sengaja dilakukan. Salah satunya sebagai bentuk perlawanan atas putusan MK yang mencabut kewenangan MPD dalam memberikan persetujuan sebagaimana yang telah penulis jabarkan di atas. Hal itu terbukti dengan munculnya badan baru yang bernama Majelis Kehormatan Notaris (MKN), yang salah satu kewe-nangan yang dimiliki MKN mengingatkan pada kewenangan MPD di Pasal 66 ayat (1) sebelum diuji dan kemudian diputuskan dibatalkan oleh MK.

Saat UU No. 2 Tahun 2014 diundangkan, tidak ada definisi resmi terkait pengertian dari MKN itu sendiri. Pada Pasal 66A UUJN-P, disebutkan MKN merupakan kepanjangan tangan dari Menteri untuk melaksanakan pembinaan kepada Notaris. MKN berjumlah 7 orang yang terdiri dari unsur Notaris (3 orang), Pemerintah (2 orang), dan Ahli/Akademisi (2 orang) (Pasal 66A ayat (2) UU No. 2 Tahun 2014). Hal ini membedakan tugas MKN dengan MPD yang memiliki wewenang mengawasi kiner-ja Notaris meskipun sama-sama dibentuk oleh Menteri.

Pasal 66 ayat (1) UUJN-P menyebutkan bahwa MKN memiliki wewenang untuk memberikan persetujuan pemanggilan Notaris dan pengambilan fotokopi Minuta akta un-tuk kepentingan proses peradilan. Adapun bunyi Pasal 66 ayat (1) sebagai berikut:

\section{Pasal 66}

(1) Untuk kepentingan proses peradilan, penyidik, penuntut umum, atau hakim dengan persetujuan Majelis Kehormatan Notaris berwenang:

a. Mengambil fotokopi Minuta akta/dan atau surat-surat yang dilekatkan pada minuta akta atau protokol Notaris dalam penyimpanan Notaris.

b. Memanggil Notaris untuk hadir dalam pemeriksaan yang berkaitan dengan akta yang dibuatnya atau protokol Notaris yang berada dalam penyimpanan Notaris.

Kehadiran badan MKN dalam UUJN-P dirasakan dapat mengembalikan kewibawaan profesi seorang Notaris sebagai pejabat umum. Namun muncul permasala- 
han baru paska hadirnya badan baru yang bernama MKN dalam UUJN-P, yakni belum terbentuknya badan itu sendiri. Pada UUJN-P, penjabaran tentang MKN bisa dibilang sangat minim dan kurang tegas. Selain tidak ditemukannya definisi yang resmi ten-tang MKN, terkait tugas, fungsi, syarat, dan tata cara pengangkatan hingga struktur organisasi MKN itu sendiri belum diketahui. Rupanya hal-hal tersebut diperintahkan oleh UUJN-P untuk diatur dalam sebuah peraturan tersendiri, yakni Peraturan Men-teri yang hingga saat ini masih dirancang (Pasal 66A ayat (3) UU No. 2 Tahun 2014).

Kehadiran MKN sudah sangat mendesak untuk segera dibentuk. Pada 2014 beberapa bulan setelah UUJN-P diundangkan, keberadaan badan MKN harus kembali meneri-ma kenyataan pahit untuk diuji di MK. Terutama terkait frasa “dengan per-setujuan Majelis Kehormatan Notaris” pada Pasal 66 ayat (1) UUJN-P. Pemohon uji materil, Tomson Situ-meang, beraganggapan hadirnya frasa tersebut menghidupkan kembali ketentuan yang telah diputus oleh MK pada 2013 lewat Keputusan MK RI No. 49/PUU/X/2012 (Anonim, "Persetujuan MKN Adalah Kunci Pembuka Kewajiban IngkarNotaris",http://www.hukumonline.com/berita/baca/lt54511017e573c/pers etujuan-mkn-adalah-kunci-pembuka-kewajiban-ingkar-Notaris, diunduh pada 15 September 2015).

Permohonan uji materil terhadap Pasal 66 ayat (1) UUJN-P ditolak oleh MK. Lembaga Negara tersebut beranggapan kehadiran MKN di UUJN-P tidak bertentangan dengan Pasal 27 ayat (1) dan Pasal 28 D ayat (1) UUD NRI 1945. Menurut Mualimin Abdi, Kepala Balitbang Kememkumham RI (2014), pembentukan MKN adalah wujud perlin-dungan bagi Notaris atas kompleksnya tugas dan kewajiban serta jaminan penggunaan hak ingkar Notaris dalam menjalankan tugasnya yang memerlukan stan-dar perlindungan baku. Keberadaan Pasal 66 ayat (1) UUJN-P justru untuk memberi perlindungan dan persamaan kedudukan di hadapan hukum kepada Notaris dalam memberi keterangan dalam proses hukum (Anonim, "Persetujuan MKN Adalah Kunci PembukaKewajibanIngkarNotaris",http://www.hukumonline.com/berita/baca/lt54 511017e573c/persetujuan-mkn-adalah-kunci-pembuka-kewajiban-ingkar-Notaris, diunduh pada 15 September 2015).

Masih ditambahkan oleh Mualimin, hasil akhir dari pemeriksaan (MKN terhadap Notaris) adalah persetujuan atau penolakan permintaan penyidik, penuntut umum, dan hakim menyangkut isi akta, fotokopi minuta, atau surat lain. Namun menurutnya, keputusan MKN ini masuk ruang lingkup keputusan tata usaha negara yang bersifat konkrit, indivi-dual, final yang menjadi obyek gugatan ke PTUN.

Menurut Habib Adjie (2015: 8), pemanggilan terhadap Notaris oleh Penyidik bisa saja terjadi apabila: (1) diungkit oleh para pihak yang namanya tersebut dalam akta; (2) oleh pihak lain yang bukan pihak dalam akta, tapi merasa dirugikan dengan terbitnya akta yang bersangkutan.

Selama MKN belum terbentuk, Notaris dapat menggunakan Hak Ingkar (Verscho-ningsrecht) dan Kewajiban Ingkar (Verschoningsplicht). Kedua hal ini sangat ja- 
Diterbitkan oleh Fakultas Hukum

Universitas Ahmad Dahlan

rang sekali digunakan Notaris pada praktiknya karena berlindung dalam kewenangan MPD (kemudian MKN, Ps. 66 ayat (1) UUJN-P). Padahal hak dan kewajiban ingkar ini otomatis melekat sejak ia menjabat. Hak dan kewajiban ingkar ini sejatinya bukan un-tuk kepentingan diri Notaris, tapi untuk kepentingan para pihak yang telah memper-cayakan kepentingannya kepada Notaris.

Hak dan kewajiban ingkar ini dapat dilakukan (digunakan) dengan batasan sepanjang diperiksa untuk meminta pernyataan/keterangam yang berkaitan dengan akta yang dibuat dihadapan Notaris (Sofyan, 2015: 6). Lebih lengkapnya hak dan kewajiban ingkar akan dibahas di pembahasan berikutnya.

Notaris dapat pula Memenuhi semua ketentuan Pasal 66 UUJN-P atas keinginan sendiri, dengan risiko dan tanggungjawab sendiri. Sehingga apabila ada yang merasa dirugikan Notaris dianggap tidak dapat menjaga rahasia jabatan. Hal ini mengacu pada Pasal 66 ayat (3) dan ayat (4) UUJN-P, yang berbunyi:

(3) Majelis Kehormatan Notaris dalam waktu paling lama 30 (tiga puluh) hari kerja terhitung sejak diterimanya surat permintaan persetujuan sebagai-mana dimaksud pada ayat (1) wajib memberikan jawaban menerima atau menolak permintaan persetujuan

(4) Dalam hal Majelis Kehormatan Notaris tidak memberikan jawaban dalam jangka waktu sebagimana dimaksud pada ayat (3), Majelis Kehormatan Nota-ris dianggap menerima permintaan persetujuan.

Ketentuan Pasal tersebut dianggap merugikan Notaris, karena tanpa bersidangnya MKN dalam jangka waktu 30 hari, dianggap telah menyetujui permintaan para penyidik. Konsep pada Pasal 66 ayat (2) dan (3) disebut konsep fiktif negatif dalam peradilan TUN. Hal ini sah-sah saja sebab yang menjadi pihak dan yang berkewajiban mengeluarkan surat adalah pemerintah. Tetapi menurut Habib Adjie (2015: 10) penerapan konsep ini tidak tepat bagi Notaris, karena bukan suatu hubungan hukum antara pemerintah dengan masyarakat.

\section{Hak dan Kewajiban Ingkar Sebagai Komponen Perlindungan Hukum Notaris Yang Integral}

Hak Ingkar ialah sebuah hak menolak sebagai imunitas hukum Notaris, untuk tidak berbicara atau memberikan keterangan apapun yang berkaitan dengan akta (atau keterangan yang berkaitan dengan akta) yang dibuat di hadapan dan/atau oleh Notaris sebagai saksi dalam penuntutan dan pengadilan (Adjie, 2015: 11). Hak Ingkar atau Verschoningsrecht didasarkan pada beberapa Pasal pada ketentuan dalam per-undang-undangan. Seperti:

a. Pasal 170 UU No. 8 Tahun 1981 tentang Hukum Acara Pidana (KUHAP):

(1) Mereka yang karena pekerjaan, harkat martabat atau jabatannya diwajibkan menyimpan rahasia, dapat minta dibebaskan dari kewaji- 
ban untuk memberi keterangan sebagai saksi, yaitu tentang hal yang dipercayakan kepada mereka

(2) Hakim menentukan sah atau tidaknya segala alasan untuk permintaan ter-sebut

b. Pasal 1909 ayat (3) Kitab Undang-Undang Hukum Perdata:

Semua orang yang cakap menjadi saksi diharuskan memberikan kesaksian di muka hakim, namun dapatlah diminta dibebaskan dari kewajibannya memberikan kesaksian:

(3) Segala siapa yang karena kedudukannya, pekerjaannya atau jabatannya menurut UU diwajibkan merahasiakan sesuatu, namun hanyalah semata-mata mengenai hal-hal yang pengetahuannya dipercayakan kepada-nya sebagai demikian.

c. Pasal 146 ayat (1) angka 3 HIR:

Boleh mengundurkan dirinya untuk memberikan kesaksian: Sekalian orang yang karena martabatnya, pekerjaan atau jawaban yang sah diwajib-kan menyimpan rahasia, akan tetapi hanya semata-mata mengenai penge-tahuan yang diserahkan kepadanya karena martabat, pekerjaan atau jaba-tannya itu.

d. Pasal 89 ayat (1) huruf b dan Pasal 89 ayat (2) UU No. 5 Tahun 1986 tentang Peradilan TUN:

(1) Orang yang dapat minta pengunduran diri dari kewajiban untuk mem-berikan kesaksian ialah:

a) Setiap orang yang karena martabat, pekerjaan, atau jabatannya diwajibkan merahasiakan segala sesuatu yang berhubungan dengan martabat, pekerjaan, atau jabatannya itu.

(2) Ada atau tidak adanya dasar kewajiban untuk merahasiakan segala se-suatu sebagaimana dimaksud dalam ayat (1) huruf b, diserahkan ke-pada pertimbangan hakim.

Selain adanya Hak Ingkar yang dapat digunakan Notaris, dikenal pula kewaji-ban Ingkar (Verschoningsplicht). Apabila Hak Ingkar didasari oleh ketentuan pada perundang-undangan lain, sebaliknya Kewajiban Ingkar adalah ketentuan yang di-perintahkan lang-sung dalam UUJN-P untuk tidak bicara, yakni:

a. Pasal 4 ayat (2) UUJN tentang Sumpah Jabatan Notaris

"Saya bersumpah/berjanji:

Bahwa saya akan patuh dan setia kepada Negara Republik Indonesia, Pancasila, dan UUD NRI 1945, UU tentang Jabatan Notaris, serta peraturan perundang-undangan lainnya. 
Diterbitkan oleh Fakultas Hukum

Universitas Ahmad Dahlan

Bahwa saya akan menjalankan jabatan saya dengan amanah, jujur, seksama, mandiri, dan tidak berpihak.

Bahwa saya akan menjaga sikap, tingkah laku saya, dan akan menjalankan kewajiban saya sesuai dengan kode etik profesi, kehormatan, martabat, dan tanggung jawab saya sebagai Notaris.

Bahwa saya akan merahasiakan isi akta dan keterangan yang diperoleh dalam pelaksanaan jabatan saya.

Bahwa saya untuk dapat diangkat dalam jabatan ini, baik secara langsung maupun tidak langsung, dengan nama atau dalih apa pun, tidak pernah dan tidak akan memberikan atau menjanjikan sesuatu kepada siapa pun."

b. Pasal 16 ayat (1) huruf $f$ UUJN-P

Merahasiakan segala sesuatu mengenai akta yang dibuatnya dan segala ke-terangan yang diperoleh guna pembuatan Akta sesuai dengan sumpah/janji jabatan, kecuali UU menentukan lain.

c. Pasal 54 ayat (1) UUJN-P

Notaris hanya dapat memberikan, memperlihatkan, atau memberitahukan isi akta, grosse akta, salinan akta, atau kutipan akta, kepada orang yang berkepentingan langsung pada akta, ahli waris atau orang yang memper-oleh hak, kecuali ditentukan lain oleh peraturan perundang-undangan.

UUJN menempatkan suatu kewajiban ingkar sebagai suatu kewajiban, hal itu berarti tidak ada pilihan memilih menggunakan atau tidak menggunakan sebab ketentuan dalam UUJN merupakan lex specialis yang mengatur langsung jabatannya sebagai pejabat umum. Mengenai batasan penggunaan kewajiban ingkar ini telah disebutkan dalam Pasal 16 ayat (1) huruf f UUJN-P, yakni "kecuali UU menentukan lain". Sehingga dalam hal ini hanya undang-undang saja yang dapat memerintahkan Notaris untuk membuka rahasia isi akta dan keterangan/pernyataan yang diketahuinya.

Berkaitan dengan sebuah kewajiban yang diatur dalam UUJN, maka pelanggaran kewajiban ini juga diancam dengan sanksi. Namun, hukuman atau sanksi yang dijatuhkan hanyalah berupa sanksi administratif berupa teguran lisan, teguran tertulis, pemberhentian sementara, pemberhentian dengan hormat, dan pemberhentian dengan tidak hormat (Pasal 54 UU No. 2 Tahun 2014).

UUJN tidak mengatur pemberian sanksi pidana bagi Notaris yang melanggar ke-wajiban ingkar. Namun pemberian sanksi pidana tunduk pada ketentuan umum pada Kitab Undang-Undang Hukum Pidana (KUHP), yakni Pasal 322 KUHP tentang membuka raha-sia dalam jabatan (Soesilo, 1995: 232):

"Pasal 322: 
(1) Barangsiapa dengan sengaja membuka sesuatu rahasia, yang menurut jabaltannya atau pekerjaannya, baik yang sekarang, maupun yang Adhi-lu, ia diwajibkan menyimpannya, dihukum penjara selamalamanya sembilan bulan atau denda sebanyak-banyaknya Rp.9400.

(2) Jika kejahatan ini dilakukan terhadap seseorang yang ditentukan, maka perbuatan itu hanya dituntut atas pengaduan orang itu."

Menurut Sigid Riyanto (2015: 12), ada beberapa persyaratan yang perlu diperhatikan dalam menerapkan Pasal 322 KUHP terkait membuka rahasia dalam jabatan Notaris. Pertama, harus dipenuhinya syarat subyetif yakni adanya kesengaja-an (dolus). Kedua, harus dipenuhinya syarat objektif yang antara lain:

a. Membuka/memberitahukan kepada pihak lain tentang sesuatu hal yang harus dirahasiakan, atau tidak boleh diberitahukan kepada pihak lain.

b. Pihak yang wajib merahasiakan mengetahui tentang hal yang harus dirahasiakan.

c. Kewajiban merahasiakan berkaitan dengan jabatan yang masih diemban atau yang pernah diemban.

d. Apabila kejahatan tentang merahasiakan ini terkait dengan perorangan, maka pemeriksaan perkara didasarkan pada pengaduan (delik aduan).

Lebih jauh lagi menurut Habib Adjie (2015: 16), ketentuan pidana bagi Notaris yang melanggar kewajiban ingkar berlaku kumulatif dan juga bisa dijerat Sanksi Pidana dan Denda dalam UU Kearsipan (lihat Pasal 85 UU No. 43 Tahun 2009 tentang Kearsipan). Relevansi dari hal ini karena akta (dan protokol Notaris) merupakan dokumen negara dan menjadi milik negara yang disimpan Notaris.

Pada praktiknya, penggunaan kedua hal ini (Hak Ingkar dan Kewajiban Ingkar) digunakan pada kondisi yang berbeda. Hak Ingkar dapat digunakan ketika Notaris dipanggil untuk diperiksa sebagai saksi di pengadilan, baik dalam perkara perdata maupun pidana. Penggunaan Hak Ingkar ini tidak serta merta langsung berlaku, melainkan membuat surat permohonan kepada hakim yang mengadili dan/atau memeriksa, bahwa Notaris akan menggunakan Hak Ingkarnya. Selanjutnya Hakim akan memutuskan untuk menolak atau mengabulkan permohonan tersebut. Apabila dikabulkan, maka Notaris tidak perlu bersaksi.

Kewajiban Ingkar digunakan ketika diperiksa sebagai saksi atau memberikan keterangan dalam proses penyidikan, dengan menyatakan akan menggunakan kewa-jiban ingkarnya sebagaimana diatur dalam UUJN-P. Pernyataan tentang penggunaan kewajiban ing-kar tersebut akan dicatat dalam berita acara pemeriksaan. Hal ini ber-sifat imperatif yang artinya wajib menggunakan ketika dilakukan penyidikan terha-dap dirinya.

Pemeriksaan kepada Notaris baik saat ditempatkan sebagai saksi untuk mem-berikan keterangan dalam proses pengadilan maupun sebagai saksi atau yang di-mintai keterangannya oleh penyidik sebenarnya tidak perlu berbicara ataupun mem-berikan keterangan lain selain apa yang ada tertuang di dalam akta yang ia buat. Nota-ris bisa saja hanya mem-bawa fotokopi akta yang dimaksud dan 
Diterbitkan oleh Fakultas Hukum

Universitas Ahmad Dahlan

kemudian memper-lihatkan kepada Hakim atau Pe-nyidik tanpa perlu memberikan kesaksian apapun. Perlu diingat, akta otentik yang menjadi produk hukum Notaris memiliki kekuatan hukum yang sempurna (apabila memang dibuat dengan benar) dan secara ex-officio para penegak hukum harus menganggap akta itu benar dan apa adanya.

\section{KESIMPULAN DAN SARAN}

Dari beberapa permasalahan yang sebelumnya telah ditentukan pada rumusan masalah dan dibahas pada bagian pembahasan, maka didapat beberapa kesimpu-lan. Antara lain:

1. Mekanisme perlindungan hukum bagi Notaris adalah dalam bentuk keten-tuan tersendiri yang terkait pemeriksaan dalam proses hukum. Hal ini diatur dalam Pasal 66 ayat (1) UU No. 30 Tahun 2004 tentang Jabatan Notaris, yang inti-sarinya ialah dibutuhkannya persetujuan oleh Majelis Pengawas Daerah (MPD) bagi penyidik, penuntut umum, maupun hakim dalam pengambilan fotokopi minuta akta dan protokol Notaris serta per-setujuan pemanggilan Notaris untuk proses pemeriksaan. Majelis Penga-was adalah suatu badan yang dibentuk oleh Menteri Hukum dan HAM, mempunyai kewenangan dan kewajiban untuk melaksanakan pembinaan dan pengawasan terhadap Notaris. Namun pada 2013 lewat Putusan Mah-kamah Konstitusi RI No. 49/PUU/X/2012 membatalkan frasa: "dengan persetujuan Majelis Pengawas Daerah" pada Pasal 66 ayat (1) UU No. 30 Tahun 2004 tentang Jabatan Notaris. Menurut MK, frasa tersebut tidak memiliki kekuatan hukum yang mengikat. Sejak saat itu pemangku ja-batan Notaris mulai merasakan kekhawatiran, sebab tanpa ketentuan ter-sebut jabatan mereka akan sangat mudah di krimi-nalisasi.

2. Majelis Kehormatan Notaris adalah badan baru yang terbentuk seiring dengan diundangkannya UU No. 2 Tahun 2014 tentang Perubahan Atas UU No. 30 Tahun 2004 tentang Jabatan Notaris (UUJN-P). Pasal 66A menyebutkan bahwa MKN merupakan badan yang merupakan kepanjangan tangan Menteri (Menteri Hukum dan HAM) yang memiliki tugas pembinaan jabatan Notaris. Salah satu kewenangan dari MKN sebagaimana dalam Pasal 66 ayat (1) UUJN-P ialah memberikan persetujuan kepada Penyidik, Penuntut Umum, atau majelis Hakim untuk meminta foto-kopi minuta akta atau protokol Nota-ris. Termasuk memanggil Notaris untuk diperiksa dalam suatu proses hukum. Kewenangan MKN tersebut mirip dengan kewenangan MPD sebelum dilak-sanakan pengujian oleh Mahkamah Konstitusi dan diputuskan bahwa "frasa dengan persetujuan Majelis Pengawas Daerah" dicabut melalui putusan No. 49/PUU/X/2012. Namun masih terdapat problematika terkait keberadaan MKN itu sendiri, sebab pengaturan lebih lanjut tentang 
badan tersebut diatur dalam Permenkumham yang hingga saat ini masih masuk dalam tahap Har-monisasi. Selama MKN belum terbentuk, Notaris dapat menggunakan Hak Ingkar dan Kewajiban Ingkar untuk melindungi jabatannya.

3. Hak Ingkar ialah hak untuk tidak berbicara atau memberikan keterangan apa-pun yang berkaitan dengan akta, sebagai saksi dalam penuntutan dan pengadilan. Keberadaan Hak Ingkar didasarkan pada beberapa Pasal dalam perundang-undangan seperti Pasal 170 UU No. 8 Tahun 1981 tentang (KUHAP), Pasal 1909 ayat (3) KUH Perdata, Pasal 146 ayat (1) angka 3 HIR, Pasal 89 ayat (1) huruf b dan Pasal 89 ayat (2) UU No. 5 Tahun 1986 tentang Peradilan TUN. Pada UUJN sendiri ketentuan ingkar ini lebih dikenal dengan nama Ke-wajiban Ingkar yang diatur dalam Pasal 4 ayat (2), Pasal 16 ayat (1) huruf f, dan Pasal 54 ayat (1). UUJN menempatkan hal tersebut sebagai suatu kewaji-ban yang secara im-peratif harus dilaksanakan. Pelanggaran ketentuan tersebut dalam UUJN lebih pada sebuah sanksi administratif pada Pasal 54, sedangkan sanksi pidananya tunduk pada ketentuan pidana umum terutama Pasal 322 KUHP tentang membuka rahasia dalam jabatan.

Penulis juga mengemukakan beberapa saran berdasarkan tulisan ini agar ke depan-nya perlindungan hukum bagi pemangku jabatan Notaris lebih mendapat kepastian hukum dan dapat dijalankan sebagaimana mestinya, yakni:

1. Pembentukan Majelis Kehormatan Notaris (MKN) sesegera mungkin dengan mendorong selesainya perumusan Peraturan Menteri Hukum dan Hak Asasi Manusia (Permenkumham) terkait badan MKN. Kemudian demi perlindungan hukum bagi Notaris yang menyeluruh, MKN sebaiknya dibentuk hingga tingkat daerah atau kabupaten/kota. Perwakilan dari unsur Notaris dalam badan MKN (3 orang) sebaiknya diajukan oleh organisasi jabatan Ikatan Notaris In-donesia (INI) melalui rapat musya-warah organisasi, bukan ditunjuk atau diten-tukan oleh Kemenkumham kepada suatu Notaris langsung.

2. Perlu diperhatikan dengan seksama terkait Pasal 66 ayat (3) dan (4) UUJN-P, karena ketentuan tersebut sedikit banyak merugikan Notaris. Sebab dalam waktu 30 hari apabila MKN tidak memberikan keputusan terkait permohonan permintaan fotokopi minuta akta, pengambilan protokol Notaris, ataupun pemanggilan Notaris oleh penyidik, penuntut umum, dan majelis Hakim maka hal itu dianggap menyetujui. Waktu yang sangat terbatas tersebut sebaiknya dapat disikapi dengan bijak oleh MKN kedepannya untuk segera menyeleng-garakan sidang pemeriksaan (dan memberikan keputusan) terhadap Notaris yang akan diperiksa dalam proses hukum. Tidak memberikan keputusan sesuai hari yang ditentukan apalagi hingga tidak melaksanakan sidang dapat berakibat fatal pada kewibawaan jabatan Notaris. 
Diterbitkan oleh Fakultas Hukum

Universitas Ahmad Dahlan

\section{DAFTAR PUSTAKA}

\section{BUKU DAN JURNAL}

Adjie, Habib (2008). Hukum Notaris Indonesia: Tafsir Tematik Terhadap UU No. 30 Tahun 2004 Tentang Jabatan Notaris. Surabaya: Refika Aditama.

(2015). Memahami Kembali Pemanggilan Notaris, Pengambilan, Penyitaan Minuta akta Notaris Oleh Penyidik Dan Perlindungan Notaris Dalam Menjalankan Tugas Jabatannya. Makalah pada Seminar Nasional: Perlindungan Hukum Terhadap Notaris Lampu Merah Oleh Majelis Kehormatan Notaris di Magister Kenotariatan FH Universitas Diponegoro 6 Juni 2015. Semarang.

Soesilo, R (1995). Kitab Undang-Undang Hukum Pidana: Serta Komentarkomentarnya Lengkap Pasal Demi Pasal. Bogor: Politeia.

Sofyan, Syafran (2015). Perlindungan Hukum Profesi PPAT-Notaris. Makalah pada Seminar Nasional: Perlindungan Hukum Terhadap Notaris Lampu Merah Oleh Majelis Kehormatan Notaris di Magister Kenotariatan FH Universitas Diponegoro 6 Juni 2015. Semarang.

Riyanto, Sigid (2015). Tindak Pidana Tertentu Yang Terkait Dengan Notaris dan PPAT. Yogyakarta: Magister Kenotariatan Universitas Gadjah Mada.

\section{PERATURAN PERUNDANG-UNDANGAN}

Kitab Undang-Undang Hukum Perdata

Undang-Undang Nomor 30 Tahun 2004 Tentang Jabatan Notaris, Lembaran Negara Republik Indonesia Tahun 2004 Nomor 117, Tambahan Lembaran Negara Republik Indonesia Nomor 4432

UU No. 5 Tahun 1986 tentang Peradilan Tata Usaha Negara, Lembaran Negara Republik Indonesia Tahun 1986 Nomor 77

UU No. 8 Tahun 1981 tentang Hukum Acara Pidana (KUHAP), Lembaran Negara Republik Indonesia Tahun 1981 Nomor 76

UU No. 2 Tahun 2014 tentang Perubahan Atas UU No. 30 Tahun 2004 tentang Jabatan Notaris, Lembara Negara Republik Indonesia Tahun 2014 Nomor 3, Tambahan Lembaran Negara Republik Indonesia Nomor 5491

\section{Internet}

http://www.hukumonline.com/berita/baca/lt54511017e573c/persetujuan-mknadalah-kunci-pembuka-kewajiban-ingkar-Notaris pada 15 September 2015 